\title{
THE IMIDAZOLINE RECEPTORS AND THE CENTRAL REGULATION OF THE ARTERIAL BLOOD PRESSURE: A MINIREVIEW
}

\author{
EDUARDO TIBIRIÇA*; GIAMPIERO BRICCA; MONIQUE DONTENWILL; \\ JOSIANE FELDMAN; HUGUES GRENEY; ALAIN BELCOURT; JEANNE STUTZMANN \& \\ PASCAL BOUSQUET
}

\begin{abstract}
* Departamento de Fisiologia e Farmacodinâmica, Instituto Oswaldo Cruz, Av. Brasil 4365, 21045-900 Rio de Janeiro, RJ Brasil Laboratoire de Pharmacologie Cardiovasculaire et Rénale, CNRS URA 589,

Faculté de Médecine, Université Louis Pasteur, 11 rue Humann, 67.000, Strasbourg, France
\end{abstract}

Recently, we proposed the hypothesis according to which the central hypotensive effect of clonidine and related substances could be related to an action upon specific receptors, requiring the imidazoline or imidazoline-like structures, rather than alpha2-adrenoceptors. Since then, direct evidences have been accumulated to confirm the existence of a population of imidazoline specific binding sites in the brainstem of animals and man, more precisely in the Nucleus Reticularis Lateralis (NRL) region of the ventrolateral medulla (VLM), site of the antihypertensive action of clonidine. The purification of the pulative endogenous ligand of the imidazoline receptors - named endazoline - is currently being attempted from human brain extracts.

This new concept might at last lead to the expected dissociation of the pharmacological mechanisms involved, on the one hand, in the therapeutic antihypertensive effect, and on the ohter, in their major side-effect, which is sedation. In fact, it has been recently confirmed that hypotension is mediated by the activation of imidazoline preferring receptors (IPR) within the $N R L$ region, while sedation is attributed to the inhibition of alpha2-adrenergic mechanisms in the locus coeruleus, which is involved in the control of the sleep-waking cycle.

The IPR may constitute an interesting target for new drugs in the treatment of arterial hypertension. Finally, dysfunctions of this modulatory system which could be involved in the pathophysiology of some forms of the hypertensive disease are under investigation.

Key words: clonidine - rilmenidine - imidazoline-preferring receptors - nucleus reticularis lateralis arterial hypotension - antihypertensive drugs - central nervous system

Several years ago we proposed the hypothesis according to which the central hypotensive effect of an imidazoline, clonidine, could not be attributed to interactions with the alpha2adrenergic receptor but rather with non-adrenergic specific imidazoline-preferring receptors (IPR), localized in the brainstem (Bousquet \& Schwartz, 1983; Bousquet et al., 1984). This assumption was first based on the crucial experimental observation that noradrenaline, the endogenous ligand of adrenoceptors, is not capable of reproducing the hypotensive effect of clonidine when it is directly injected in the ventrolateral part of the medulla oblongata, more precisely in the Nucleus Reticularis

Received 8 September 1992. Accepted 9 November 1992.
Lateralis (NRL) region, which is the main site of the hypotensive effect of clonidine-type drugs in various species (Bousquet et al., 1975, 1981; Wolf \& Mohrland, 1984; Gillis et al., 1985; Reis et al., 1988; McAuley et al., 1989). We then performed a wide structure/activity relationship study which showed that the microinjection of several alpha-adrenergic agonists - bearing either a catecholamine or a phenylethylamine structure - in the NRL region of the anesthetized cat, never induced any reduction in arterial pressure, even with compounds highly selective for the alpha2adrenoceptors such as alpha-methylnoradrenaline (Bousquet et al., 1984). However, the administration of various imidazolines in the same experimental conditions always elicited a dose-dependent decrease in arterial pressure, independently of their selectivity for one or 


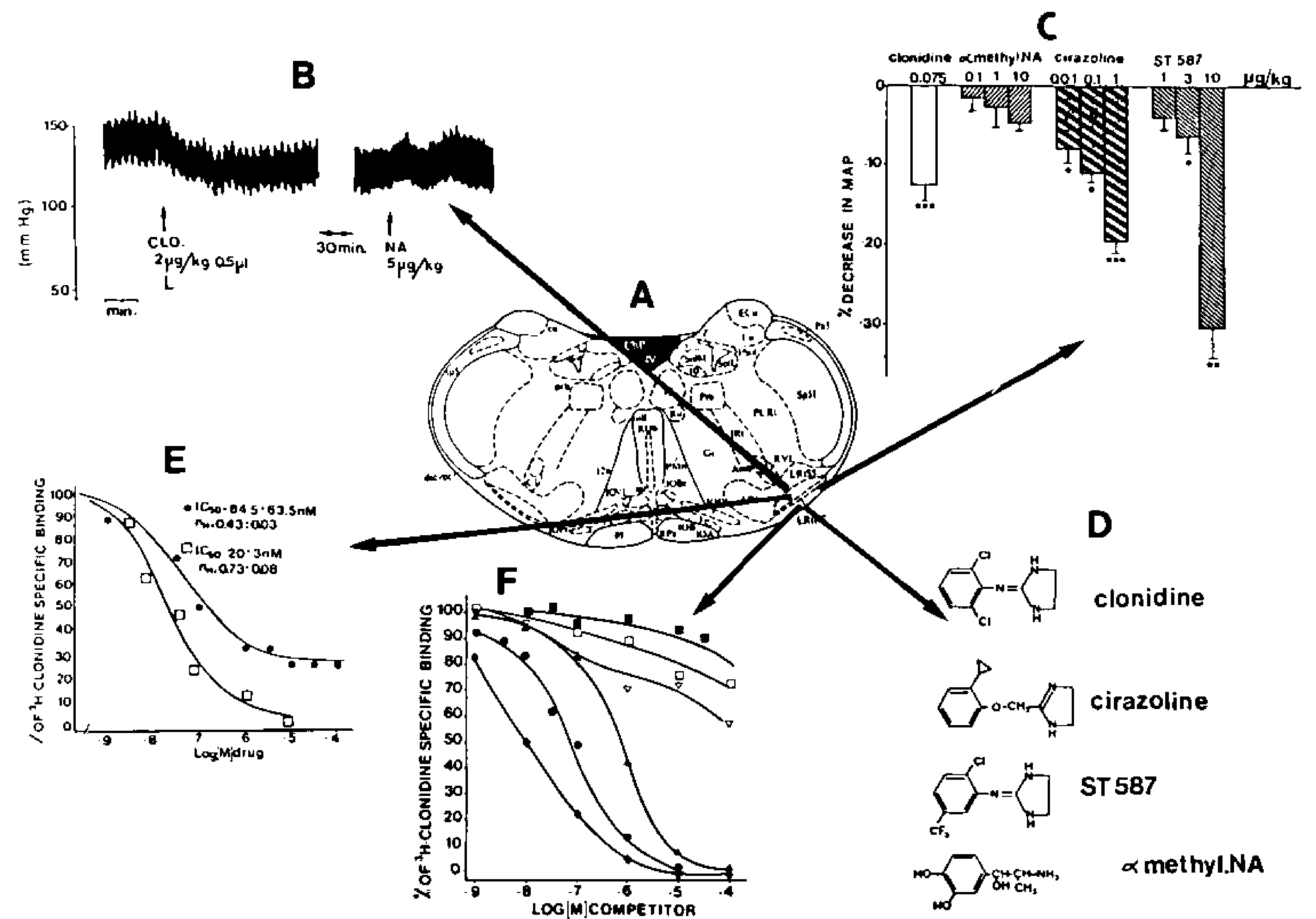

Fig. 1: A - Frontal section of the brainstem of the rat at the level of the Nucleus Reticularis Lateralis (NRL). B Hypotensive effect induced by clonidine (CLO) upon microinjection in the NRL region; injection of noradrenaline (NA) has no effect on blood pressure. $\mathrm{C}$ - Effects on the mean arterial pressure of some imidazolines microinjected in the NRL region - chemical structures are given in D - alpha-methylnoradrenaline has no hypotensive effect. $\mathrm{E}$ - Displacement of $\left[{ }^{3} \mathrm{H}\right]$ clonidine specific binding to bovine NRL membrane preparations by $\square$ clonidine and noradrenaline $\cdots$ about $30 \%$ of specifically bound $\left[{ }^{3} \mathrm{I}\right]$ clonidine was not displaced by the catecholamine. F $\left[{ }^{3} \mathrm{H}\right]$ clonidine specific binding to human NRL membrane preparations was virtually unaffected by catecholamines:

(-)noradrenaline, $\square$ (-)adrenaline and $\nabla$ alpha-methylnoradrenaline, but completely inhibited by imidazolines:

$\Delta$ ST 587,0 clonidine and $\bullet$ cirazoline.

the other sub-type of alpha-adrenoceptors (Bousquet et al., 1984). In fact, the imidazolines cirazoline and ST 587, two selective alpha1adrenoceptor agonists, induced marked hypotensive effects when microinjected in the NRL region (Fig. 1).

These results were later on confirmed in the anesthetized rat. In fact, a variety of imidazoline-containing substances induced hypotension when injected in the rostral ventrolateral medulla oblongata. No direct correlation could actually be established between the affinities of these imidazoline compounds for alpha-adrenoceptors and their ability to induce arterial hypotension (Ernsberger et al., 1987, 1988a, 1990).

In peripheral experimental models also, Ruffolo and coworkers demonstrated that the phenylethylamines and the imidazolines dis- play different pharmacological mechanisms of action in various tissues (for review see Ruffolo, 1991). They observed, for instance, the absence of cross-desensitization of the rat vas deferens to the contractile action of phenylethylamines (noradrenaline, methoxamine, phenylephrine) and imidazolines (oxymetazoline, tetrahydrozoline), suggesting the existence of two distinct binding sites to alphaadrenoceptor agonists belonging to these different chemical families.

These receptors do not belong to the histamine receptors family either, since histamine antagonists bearing an imidazole moiety such as metiamide or cimetidine do not prevent the central hypotensive effect of clonidine or of related compounds.

Taken together, these experimental findings suggest that the activation of receptors 
specifically sensitive to the imidazoline structure in the brainstem could inhibit the sympathetic outflow to the periphery and thus lower arterial pressure.

In the recent period, the existence of such specific binding sites has been demonstrated in a great variety of tissues and species (Coupry et al., 1987; Hamilton et al., 1988; Yablonsky et al., 1988; Langin \& Lafontan, 1989; Parini, 1989; Wikberg, 1989; Michel et al., 1990; Portillo et al., 1991). Moreover, the purification of the receptor and of its putative endogenous ligand is currently being attempted in several laboratories (Atlas \& Burstein, 1984a, b; Meeley et al., 1986; Ernsberger et al., 1988b; Belcourt et al., 1990).

These findings led us to a complete reevaluation of our concepts concerning not only the mechanism of action of centrally acting antihypertensive drugs like clonidine but also some aspects of the central regulation of arterial pressure. Consequently, as soon as the hypotensive action of these drugs is related to the activation of non-adrenergic imidazolinespecific receptors, it became theoretically possible to dissociate the pharmacological mechanisms involved in their therapeutic (hypotensive) action and in their major side effect, which is sedation. In fact, the sedative effect of clonidine has been attributed to an action within the nucleus locus coeruleus (LC), a noradrenergic structure of the reticular system, which is directly involved in the regulation of the sleep-waking cycle (Jouvet, 1972, 1973; Cespuglio et al., 1982). The activation of alpha2-adrenoceptors by clonidine in the LC leading to a consequent inhibition of noradrenergic neurons will result in a sedative effect (Amaral \& Sinnamon, 1977; Redmond, 1981; De Sarro et al., 1987).

BIOCHEMICAL CHARACTERIZATION OF IMIDAZOLINE-SPECIFIC BINDING SITES IN THE CENTRAL NERVOUS SYSTEM

It is well-known that the specific binding of $\left[{ }^{3} \mathrm{H}\right]$ clonidine in most tissue preparations can be completely displaced by catecholamines and also by alpha-adrenergic agonists belonging to different chemical families (for review see Kobinger, 1978; Timmermans \& Van Zwieten, 1982). However, in the past few years strong evidence has accumulated to confirm the existence of imidazoline-specific binding sites in the central nervous system which are completely insensitive to catecholamines. In 1987 , it was reported for the first time that a sub-population of the $\left[{ }^{3} \mathrm{H}\right] \mathrm{p}$-aminoclinidine binding sites in membrane preparations obtained from the ventrolateral area of the bovine medulla oblongata, was catecholamine insensitive (Ernsberger et al., 1987).

In fact, about $30 \%$ of the sites labelled by $\left[{ }^{3} \mathrm{H}\right] \mathrm{p}$-aminoclonidine could not be displaced by an excess of noradrenaline (Meeley et al., 1986; Ernsberger et al., 1987). Since then, the existence of non-adrenergic binding sites specific to imidazolines has been reported in the central nervous system of different species using: (i) $\left[{ }^{3} \mathrm{H}\right]$ clonidine, in the bovine ventrolateral medulla oblongata (Bricca et al., 1989a) and human brainstem (Bricca et al., 1988, $1989 \mathrm{a}, \mathrm{b}$ ) and (ii) $\left[{ }^{3} \mathrm{H}\right]$ idazoxan, in the rabbit cortex (Hamilton et al., 1988; Covents et al., 1989), guinea pig cortex (Wikberg, 1989) and human brain (Covents et al., 1989; De Vos et al., 1991). It is noteworthy that in the NRL region isolated from human brainstem, catecholamines had virtually no effect on the specific binding of $\left[{ }^{3} \mathrm{H}\right]$ clonidine while imidazolines (cirazoline, ST 587) induced complete displacement (Fig. 1) (Bricca et al., 1988). The latter results point out the existence of a high proportion of sites specifically sensitive to imidazolines in human membrane preparations from this area of the brainstem, including the NRL region.

In this context, it was shown that the ability of a series of imidazolines to induce arterial hypotension when injected in the rostral ventrolateral medulla of the anesthetized rat, is well correlated with their ability to inhibit the non-adrenergic component of $\left[{ }^{3} \mathrm{H}\right] \mathrm{p}$ aminoclinidine binding in bovine ventrolateral medulla, but not with the inhibition of binding to alpha2-adrenoceptors in the frontal cortex (Ernsberger et al., 1990).

Further discrimination between the imidazoline specific binding sites and the alpha2adrenoceptors has been provided by the demonstration of the insensitivity of the former to GTP or to its non hydrolysable analog $\mathrm{Gpp}(\mathrm{NH}) \mathrm{p}$, while the binding of the same radioligands to alpha2-adrenoceptors is affected by this treatment (Wikberg \& Uhlen, 1990; Bricca et al., in press). For instance, the imidazoline-specific binding sites of $\left[{ }^{3} \mathrm{H}\right]$ clonidine and $\left[{ }^{3} \mathrm{H}\right]$ idazoxan to human NRL membrane preparations (Greney et al., 1992) or to 
adrenal chromaffin cell membranes (Reis et al., 1992), which are obviously insensitive to catecholamines, are not affected by $\mathrm{Gpp}(\mathrm{NH}) \mathrm{p}$, thus suggesting that the IPR is not coupled to a GTP-binding protein. The signal transduction mechanism(s) associated with the stimulation of the IPR are not yet known. However, it does not seem to be coupled to classical Gprotein pathways, which provides additional evidence that the IPR and alpha2-adrenoceptors are distinct receptor systems. The coupling of the IPR to a $\mathrm{K}^{+}$channel has already been suggested based on the observation that idazoxan binding is highly sensitive to $\mathrm{K}^{+}$ions (Coupry et al., 1989); nevertheless, this issue deserves further investigation.

Finally, it was shown that the imidazoline binding sites and the alpha2-adrenoceptors constitute physically distinct entities, as they can be separated by several purification procedures, and the IPR retain their pharmacological characteristics in the purified state (Michel et al., 1990; Wikberg \& Uhlen, 1990; Parini et al., 1989). In fact, the partial purification of the kidney (Parini et al., 1989; Limon et al., 1992) or cerebral (Greney et al., 1992) imidazoline specific binding sites using $\left[{ }^{3} \mathrm{H}\right]$ clonidine and $\left[{ }^{3} \mathrm{H}\right]$ idazoxan, yields two distinct solubilized sites that retain the same pharmacological profile of the membrane binding sites: the first one corresponds to an alpha2-adrenoceptor while the second one is insensitive to catecholamines and GTP, and presents all the binding characteristics of the imidazoline-specific site. However, the total purification of the IPR has to be achieved in order to allow the characterization of the molecular properties of this receptive protein.

\section{FUNCTIONAL STUDIES}

The aforementioned studies provided strong evidence to the existence of imidazoline binding sites in the central nervous system, which are supposed to be associated with the modulation of the vasomotor tone. In order to ascertain this hypothesis we recently performed in vivo functional experiments. Thus, we used an in vivo electrochemistry technique, differential voltammetry, to study in parallel the effects of clonidine-like drugs on the cardiovascular parameters and on the metabolic activity of the catecholaminergic neurons of the NRL region (Fig. 2) (Tibiriçá et al., 1989). This technique allows to measure the variations in the extracelfular concentrations of a catecholamine metabolite - DOPAC (3,4-dihydroxyphenylacetic acid) - which is released by the noradrenergic cell bodies (Buda \& Gonon, 1987). The activity thus measured is considered to be a reliable index of the global neuronal activity (Suaud-Chagny et al., 1986; Buda \& Gonon, 1987; Tibiriçá et al., 1989, 1991a, b; Lambas-Señas et al., 1990).

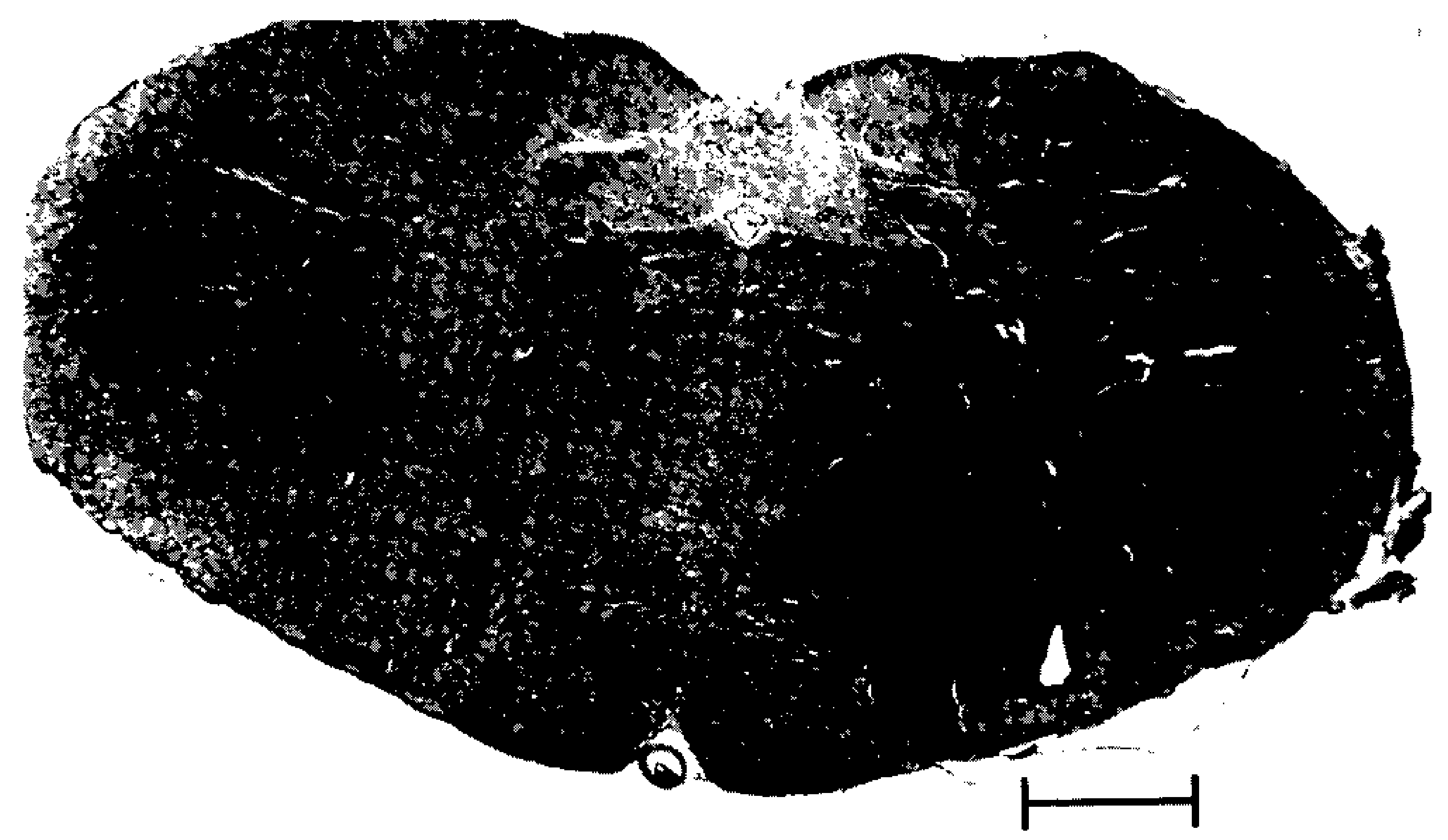

Fig. 2: photomicrograph of a coronal section of the rat medulla oblongata showing the electrochemical lesion (arrow) performed by means of the carbon fiber microelectrode at the end of the experiment. Calibration scale: 1 $\mathrm{mm}$. 


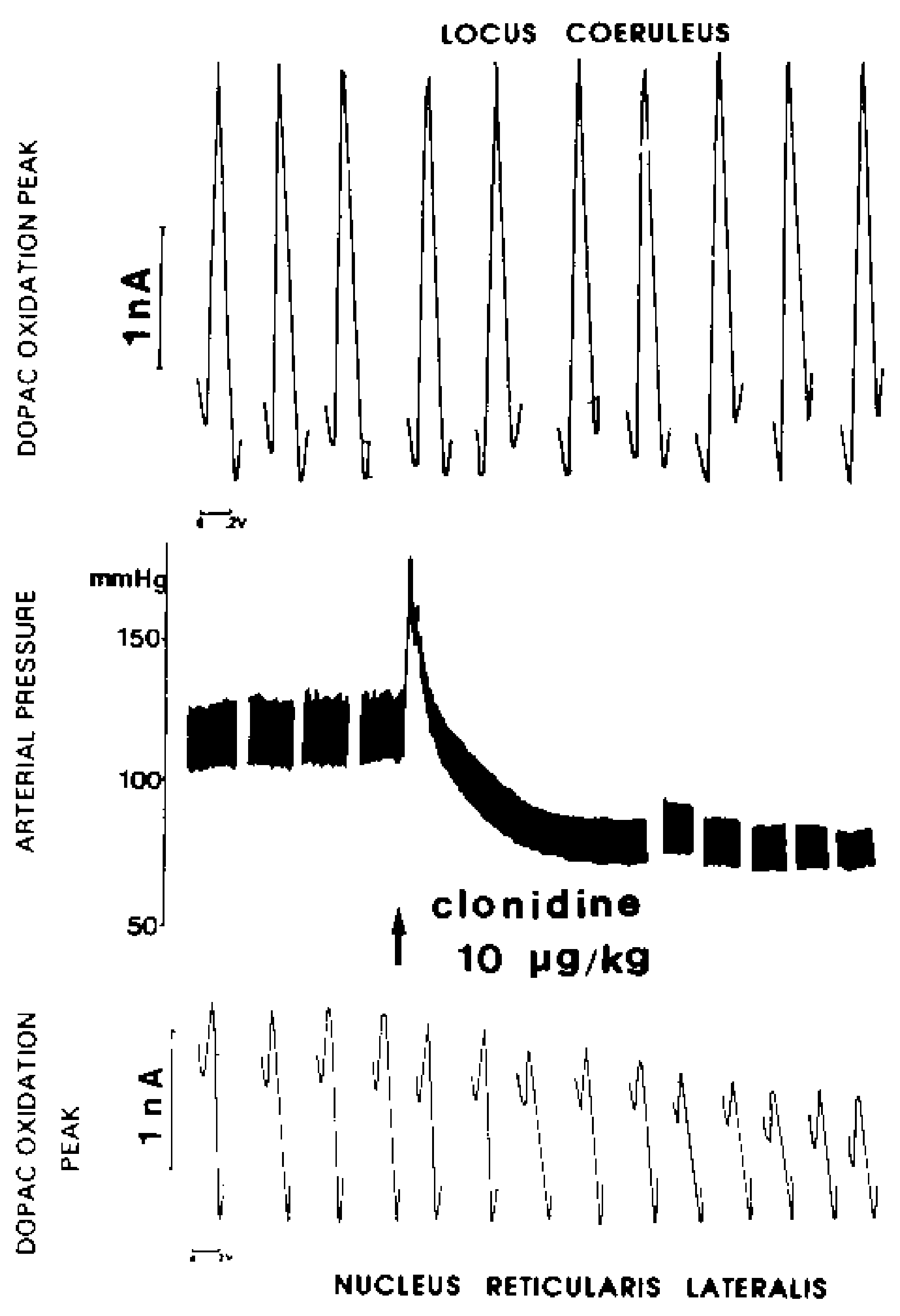

Fig. 3: representative tracings depicting the effects of clonidine $(10 \mu \mathrm{g} / \mathrm{kg})$ on the neuronal metabolic activity of noradrenergic neurons -.. represented by the catechol (I)OPAC) oxidation peak height in the locus coeruleus (top) and in the NRL region (bottom) and on the arterial pressure (middle tracing) of the pentobarbital anesthetized rat. The intravenous administration of clonidine induces marked and parallel reductions on arterial pressure and on the neuronal metabolic activity recorded in the NRL region but not in the locus coeruleus, when used in this rather low dose.

We then studied the influence of centrally acting antihypertensive drugs of the clonidine type on the metabolic activity of noradrenergic neurons of the NRL and locus coeruleus regions in pentobarbital anesthetized rats (see introduction). We demonstrated that low doses of clonidine, starting from $2 \mu \mathrm{g} / \mathrm{kg}$ intravenously injected, induced parallel and marked reductions on the neuronal metabolic activity in the NRL region and on arterial pressure. The kinetics of both effects are parallel and reach a plateau $20 \mathrm{~min}$ after clonidine injection by the intravenous route (Tibiriça et al., 1989). A positive correlation has been established between these effects $20 \mathrm{~min}$ after injection, at clonidine doses ranging from 2 to $10 \mu \mathrm{g} / \mathrm{kg}$, i.v. (Tibiriçá et al., 1989). This parallelism between the hypotensive and ventro- lateral medullary neuronal inhibitory effects of clonidine became particularly evident for a dose of $10 \mu \mathrm{g} / \mathrm{kg}$, suggesting the existence of a close relationship between these two effects of clonidine (Fig. 3). However, these same doses of clonidine did not affect the neuronal activity in the LC, where an inhibitory effect could only be observed when doses 25 times higher were used, showing that the drug prefcrentially acts in the NRL region, which contains non-alpha adrenergic IPR involved in the cardiovascular regulation (Mecley et al., 1986; Emsberger et al., 1987, 1988a; Briced et al., $1988)$.

In order to further characterize the pharmacological mechanisms involved in these central effects of clonidine, we reassessed the antagonistic potencies of two clonidine antagonists: (i) idazoxan, which contains an imidazoline ring and is known to label imidazoline-specific sites in the central nervous system (Hamilton et al., 1988; Michel et al., 1988, 1990; Bricca et al., in press) and (ii) yohimbine, a classical alpha2-adrenoceptor antagonist with very low affinity for the IPR (Goldberg \& Robertson, 1983; Hamilton et al., 1988). The antagonists were intracisternally injected in order to rule out any variability in the results which could be duc to heterogeneity in crossing the blood-brain barrier. They were used in very low equimolecular doses (5 nmol $/ \mathrm{kg}$ ), which ensured their selectivity for one or the other type of receptors (Tibiriçá et al., 1988, 1991a). Indeed, this dose of yohimbine is about 100 times lower than the lowest dose generally used to antagonize the hypotensive effect of clonidine (for review see Goldberg \& Robertson, 1983). Under these experimental conditions, prior administration of idazoxan, but not yohimbine, almost completely prevented not only the hypotensive but also the medullary neuronal inhibitory effects of systemically administered clonidine (Tibiriçá et al., 1991a). In contrast, in the LC, the effects of the antagonists on the neurochemical changes induced by clonidine were reciprocal to those observed in the NRL region. Here is yohimbine that behaves as an antagonist of the neuronal inhibitory effects of clonidine, while idaxozan had virtually no effect on the neuronal inhibitory effects of the drug (Tibircad et al., 199la). Thus, it is now possible to dissociate the pharmacological mechanisms involved in the hypotensive and sedative effects of imidazolines and related compounds. In other words, the clonidine-induced blood pressure 
NUCLEUS RETICULARIS $\square$ MEAN ARTERIAL PRESSURE LATERALIS RILMENIDINE

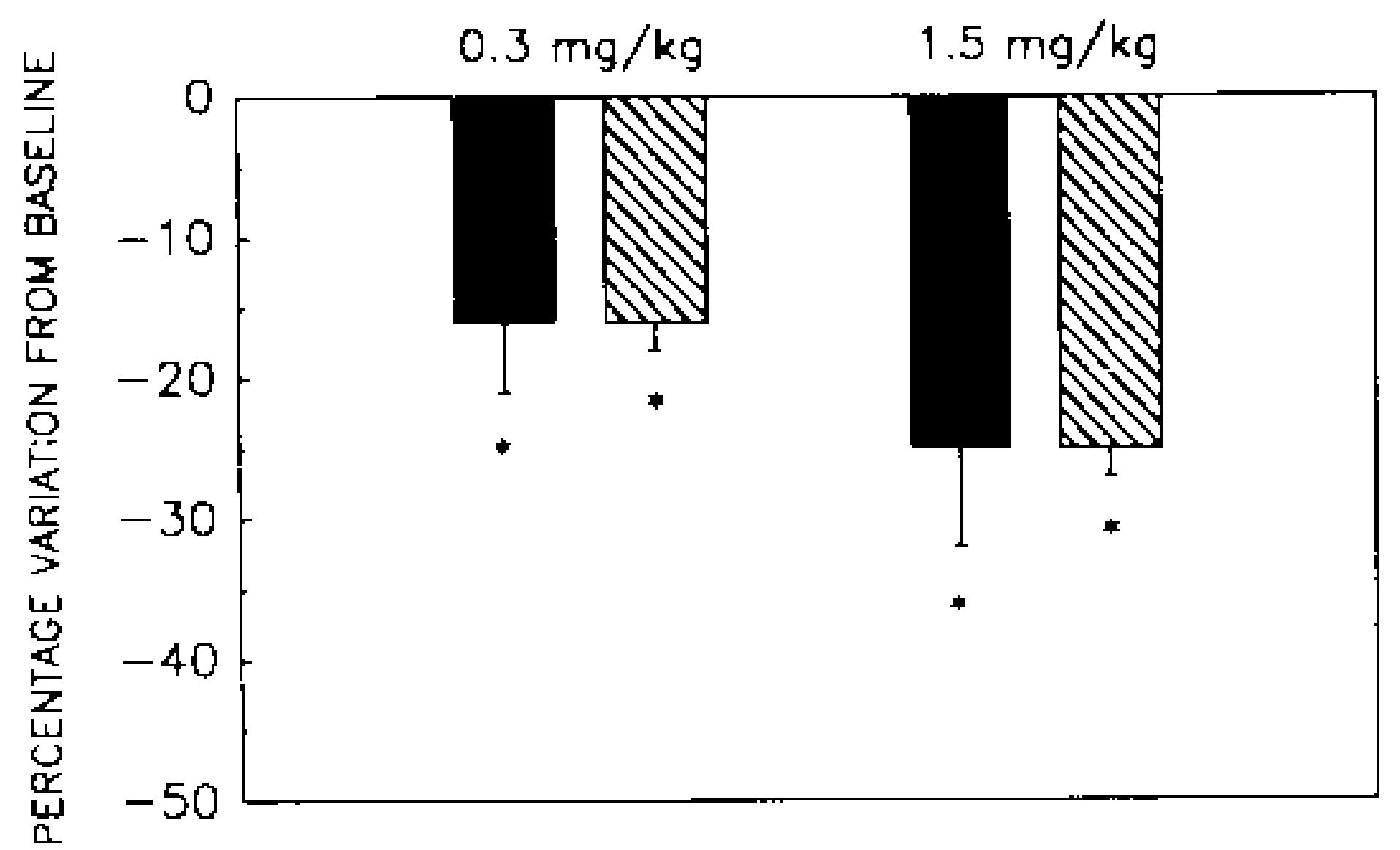

LOCUS COERULEUS

CATECHOL OXIDATION PEAK SIIV MEAN ARTERIAL PRESSURE

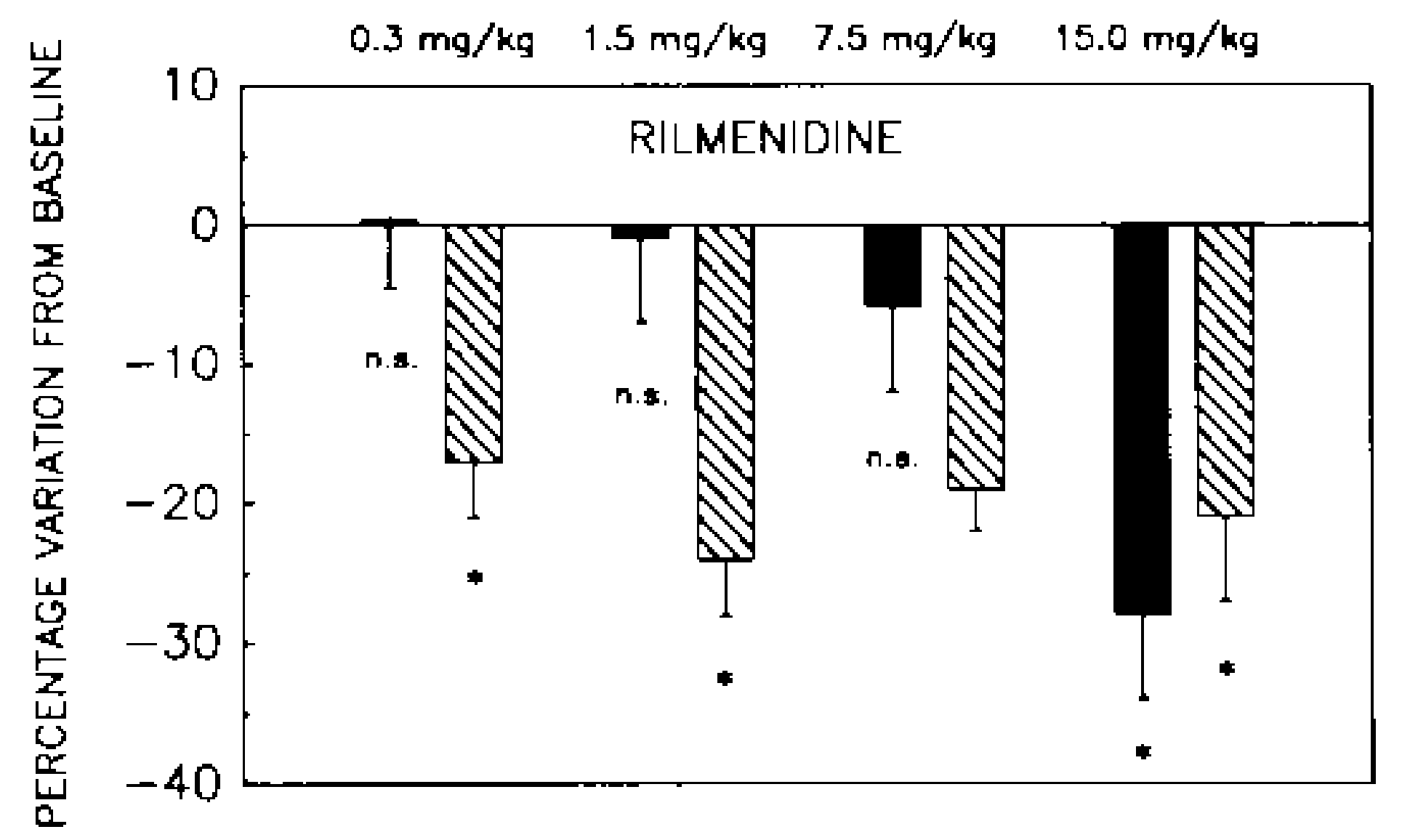

Fig. 4: comparison between the maximal inhibitory effects of increasing doses of i.v. rilmenidine on the neuronal metabolic activity recorded in the NRL (upper pancl) and locus coeruleus (lower pancl) regions and on arterial pressure of the pentobarbital anesthetized rat. The variations of the catechol oxidation peak height are expressed as the percentage of the bascline period. defined as the mean height of the 15 peaks recorded before injection of rilmenidine or saline solution (con)trol experiments). Doses of rilmenidine 50 times higher than the ones which induce hypotension and inhibit the noradrenergic neurons of the NRL region are necessary to reduce the neuronal activity in the locus coeruleus. * $P<0.05$ : significantly different from the control group; n.s.: non significant effect. (ANOVA and NewmanKeuls' test).

decreasing effect triggered in the NRL region is clearly related to IPR while the $\mathrm{LC}$ effects of the drug imply classical alpha2-adrenoceptors.

Rilmenidine, an oxazoline, is a new centrally acting antihypertensive drug structurally related to clonidine, that has been recently introduced in the drug therapy of hypertension in Europe (Laubie ct al., 1985; Van Zwieten et al., 1986; Koenig-Berard et al., 1988). Rilmenidine is characterized by an absence of sedative effect in laboratory animals and very low incidence of sedation in humans at doses that induce hypotension (Fillastre et al., 1988; Koenig-Berard et al., 1988). Rilmenidine presents a pharmacological profile similar to that of clonidine, but it is twice as selective as clonidine to the NRL region, comparing to the $\mathrm{LC}$, as shown by voltammetric studies using the same experimental procedures described above (Fig. 4) (Tibiriçá et al., 1991b). Moreover, these functional studies were confirmed by biochemical data showing that rilmenidine is two to three times more selective for the imidazoline receptor in the NRL region, when compared to the cortical alpha2-adrenoceptors, than clonidine itself (Bricca et al., 1989b). It is noteworthy that the hypotensive effect induced by rilmenidine in the pentobarbital anesthetized rabbit is more efficiently antagonized by idazoxan, the imidazoline antagonist, than by yohimbine (Feldman et al., 1990).

In conclusion, these studies confirm that antihypertensive drugs more selective than the reference substance clonidine for the IPR, when compared to alpha2-adrenoceptors, and acting preferentially on the neurons of the NRL region, would present no important sedative effect.

\section{CLINICAL IMPLICATIONS}

As stated above, the IPRs are involved in the central hypotensive effect of clonidine and related substances as well as in the modulation of the vasomotor tone regulation. Thus, dysfunctions of this system could be associated with the pathophysiology of some forms of arterial hypertension. In this respect, we developed poly- and monoclonal antibodies directed against clonidine, using p-aminoclonidine coupled to hemocyanin by glutaraldehyde as immunogen (Dontenwill et al., 1987, $1988,1992 \mathrm{a}, \mathrm{b})$. These antibodies showed to be highly specific to substances structurally related to clonidine and they do not cross-react at all with catecholamines or any other endogenous mediator bearing an imidazole moiety (Dontenwill et al., 1992a).

In other transmitter systems, antibodies developed against exogenous ligands of the receptor have proved to recognize the corresponding endogenous mediator, as is the case of anti-alprenolol antibodies that recognize endogenous catecholamines (Rockson et al., 1980). Consequently, these anti-clonidine antibodies can be useful tools not only for the immuno- 
purification of the endogenous ligand of the IPRs but also to the purification of the receptor itself, by the use of anti-idiotypic antibodies. In fact, it was possible to detect, using the anti-clonidine antibodies in radioimmunoassays, the existence of an immunoreactive substance in the human serum. Our preliminary results revealed that this immunoreactive substance is present in quite high concentrations in the plasma of some untreated patients with essential hypertension, while rather low concentrations were detected in the plasma of normotensive subjects devoid of any cardiovascular discase (Dontenwill et al., 1992b). However, the identity of this immunoreactive substance with the putative endogenous ligand of the imidazoline receptors, endazoline (Feldman et al., 1990), deserves the complete purification of the substance and consequent identification of its chemical structure.

\section{CONCLUDING REMARKS}

In the past few years it became apparent that the imidazoline specific binding sites in the brain, which are distinct from the alpha2adrenergic receptors, represent functional receptors involved in the modulation of the central sympathetic activity and consequently in the regulation of the vasomotor tone. Moreover, the IPRs of the ventrolateral medulla oblongata play an important role in the mechanism of action of clonidine and related substances, such as rilmenidine. The demonstration of the duality of pharmacological mechanisms involved in the hypotensive and sedative effects of these drugs - the former attributed to an activation of imidazoline receptors in the NRL region and the latter to an activation of alpha2-adrenergic receptors in the locus coeruleus - opens new ways to the development of new centrally acting antihypertensive drugs devoid of sedative effect and provides insights in the pathophysiology of some forms of arterial hypertension.

\section{REFERFNCES}

AMARAL, D. G. \& SINNAMON, H. M., 1977. The locus coeruleus, neurobiology of a central noradrenergic nucleus. Progr. in Neurobiol. 9: 147196.

ATLAS, D. \& BURSTEIN, Y., 1984a. Isolation of an endogenous clonidine-displacing substance from rat brain. FEBS Lett., 170: 387-390.

ATLAS, D. \& BURSTEIN, Y., 1984b. Isolation and partial purification of a clonidine -displacing endogenous brain substance. Eur. J. Biochem., 144: 287. 293.
BELCOURT, A.; GRENEY, H.; BRICCA, G.; DONTENWILL, M. \& BOUSQUET, P., 1990. Partial purification of the human endazoline, the specific endogenous ligand for imidazoline receptors. Eur. J. Pharmacol, 183: 852-853.

BOUSQUET, P.; FELDMAN, J.; BLOCH, R. \& SCHWARTZ, J., 1981. The nucleus reticularis lateralis: a region highly sensitive to clonidine. Eur. J. Pharmacol., 69: 389-392.

BOUSQUET, P.; FELDMAN, J.; VELLY, J. \& BLOCH, R., 1975. Role of the ventral surface of the brain stem in the hypotensive action of clonidine. Eur. $J$. Pharmacol., 34: 151-156.

BOUSQUET, P.; FELDMAN, J. \& SCHWARTZ, J., 1984. Central cardiovascular effects of alpha-adrenergic drugs: Difference between catecholamines and imidazolines. J. Pharmacol. Exp. Ther., 230: 230-236.

BOUSQUET, P. \& SCHWARTZ, J., 1983. Alpha-adrenergic drugs: pharmacological tools for the study of the central vasomotor control. Biochem. Pharmacol., 32: 1459-1465.

BRICCA, G.; DONTENWILL, M.; GRENEY, H.; STUTZMANN, J.; BELCOURT, A. \& BOUSQUET, P., 1992. Int. Neurochem. (in press).

BRICCA, G.; DONTENWILL, M.; MOLINES, A.; FELDMAN, J; BELCOURT, A. \& BOUSQUET, P., 1988. Evidence for the existence of a homogenous population of imidazoline receptors in the human brainstem. Eur. J. Pharmacol., 150: 401 402.

BRICCA, G.; DONTENWILL, M.; MOLINES, A.; FELDMAN, J.; BELCOURT, A. \& BOUSQUET, P., 1989a. The imidazoline preferring receptor: binding studies in bovine, rat and human brainstem. Eur. J. Pharmacol, 162: 1-9.

BRICCA, G.; DONTENWILL, M.; MOLINES, A.; FELDMAN, J.; TIBIRICA, E.; BHLCOURT, A. \& BOUSQUET, P., 1989b. Rilmenidine selectivity for imidazoline receptors in the human brain. Eur. $J$. Pharmacol., 163: 373-377.

BUDA, M. \& GONON, F., 1987. Study of brain noradrenergic neurons by use of in vivo voltammetry, p. 239-272. In J. B. Justice Jr., Voltammetry in the Neurosciences, Humana Press Inc., Clifton, NJ, U.S.A.

CESPUGLIO, R.; GOMEZ, M. E.: FARADJI, H. \& JOUVET, $M, 1982$. Alterations in the sleep-waking cycle induced by cooling of the locus coeruleus area. Electroencephalogr. Clin. Neurophysiol., 54 . $570-578$.

COVENTS, A.: COVENTS, D.; DeBACKER, J. P.; DeKAYSER, J. \& VAUQUELIN, G., 1989. High aflinity binding of [3H] rauwolscine and [3H] RX 781094 to alpha2-adrenergic receptors and nonstereoselective sites in human and rabbit cortex membranes. Biochem. Pharmacol., 38: 455-463.

COUPRY, I.; LACHAUD, V.; PODEVIN, R. A.; KOENIG, E. \& PARINI, A., 1989. Different affinitics of alpha2 agonists for imidazoline and alpha2adrenergic receptors. Am. J. Hyperten., 2: 468-470.

COUPRY, 1.; PODEVIN, R. A.; DAUSSE, J. P. \& PARINI, A., 1987. Evidence for imidazoline binding sites in basolateral membranes from rabbit kidney. Biochem. Biophys. Res. Comm. 147: 10551060 . 
De SARRO, G. B.; ASCIOTI, C.; FROIO, F.; LIBRI, V. $\&$ NISTICO, G., 1987. Evidence that the locus coeruleus is the site where clonidine and drugs acting at alphal- and alpha2-adrenoceptors affect sleep and arousal mechanisms. Br. J. Pharmacol., 90: 675-685.

De VOS, H.; COVENTS, A.: DeKEYSER, J.; DeBACKER, J. P.; VanMEGEN, I. J. B.; EBINGER, G. \& VAUQUELIN, G., 1991. Autoradiographic distribution of alpha2-adrenoceptors, NAIBS and 5-HT IA receptors in human brain using $\left[{ }^{3} \mathrm{H}\right]$ idazoxan and $\left[{ }^{3} \mathrm{H}\right]$ rauwolscine. Brain Res., 566: 13-20.

DONTENWILL, M.; BRICCA, G.; MOLINES, A.; BELCOURT, A. \& BOUSQUET, P., 1987. A polyclonal antibody raised against clonidine: a model for the specific imidazoline receptor. Eur. $J$. Pharmacol., 137: 143-144.

DONTENWILL, M.; BRICCA, G.; MOLINES, A.; BOUSQUET, P. \& BELCOURT, A., 1988. Production and characterization of anti-clonidine antibodies not cross-reacting with catecholamines. Eur. J. Pharmacol., 149: 249-255.

DONTENWILL, M.; MOLINES, A.; BRICCA, G.; STUTZMANN, J.; KEMPF, J.; BELCOURT, A. \& BOUSQUET, P., 1992a. Production and characterization of an iminoimidazolidine specific monoclonal antibody using para-aminoclonidine as antigen. Life Sci, 50: 1859-1868.

DONTENWILL, M.; MOLINES, A.; VERDUN, A.; BRICCA, G.; BELCOURT, A. \& BOUSQUET, P., 1992b. A circulating imidazoline-like substance cross-reacts with anti-clonidine antibodies; high levels in hypertensive patients. Fundam. Clin. Pharmacol, 6 (suppl) 1: 49s.

ERNSBERGER, P. R.; GIULIANO, R.; WILLETTE, R. N.; GRANATA, A. R. \& REIS, D. J., 1988a. Hypotensive action of clonidine analogs correlate with binding affinity at imidazole and not alpha2. adrenergic receptors in the rostral ventrolateral medulla. Hypertension. 6 (suppl. 4): S554-S557.

ERNSBERGER, P. R.; GIULIANO, R.; WILLETTE, R. N. \& REIS, D. J., 1990. Role of imidazole receptors in the vasodepressor response to clonidine analogs in the rostral ventrolateral medulla. J. Pharmacol. Exp. Ther., 253: 408-418.

ERNSBERGER, P. R.; MEELEY, M. P.; MANN, J. J. \& REIS, D. J., 1987. Clonidine binds to imidazole bindings sites as well as alpha2-adrenoceptors in the ventrolateral medulla. Eur. J. Pharmacol., 134: $1-13$.

ERNSBERGER, P. R.; MEELEY, M. \& REIS, D. J., $1988 \mathrm{~b}$. An endogenous substance with clonidinelike properties: Selective binding to imidazole sites in the ventrolateral medulla. Brain Res., 441: 309. 318.

FELDMAN, J.; TIBIRICA. E.; BRICCA, G.; DONTENWILL, M.; BELCOURT, A. \& BOUSQUET, P., 1990. Evidence for the involvement of imidazoline receptors in the central hypotensive effect of rilmenidine in the rabbit. $\mathrm{Br}$. J. Pharmacol, 100: 600. 604.

FILLASTRE, J. P.; LETAC, B.; GALINIER, F.; LeBIHAN, G. \& SCHWARTZ, J., 1988. A multicenter double-blind study of rilmenidine and clonidine in 333 hypertensive patients. Am.J. Cardiol., 61: 81D.
GILLIS, R. A.; GATTI, P. J. \& QUEST, J. A., 1985. Mechanism of the antihypertensive effect of alpha2agonists. J. Cardiovasc. Pharmacol, 7 (suppl 8): S38-S44.

GOLDBERG, M. R. \& ROBERTSON, D., 1983. Yohimbine: A pharmacological probe for study of the alpha2-adrenoceptors. Pharm. Rev., 35: 143 170.

GRENEY, H.; BRICCA, G.; DONTENWILL, M.; BELCOURT, A. \& BOUSQUET, P., 1992. [ $\left.{ }^{3} \mathrm{H}\right]$ idazoxan and $\left[{ }^{3} \mathrm{H}\right]$ clonidine binding in the human nucleus reticularis lateralis (NRL). Fundam. Clin. Pharmacol., 6 (suppl I): $51 \mathrm{~s}$.

HAMILTON, C. A.; REID, J. D. \& YAKUBU, M. A., 1988. [ $\left.{ }^{3} \mathrm{H}\right]$ Yohimbine and $\left[{ }^{3} \mathrm{H}\right]$ idazoxan bind to different sites on rabbit forebrain and kidney membranes. Eur. J. Pharmacol., 146: 345-348.

JOUVET, M., 1972. The role of monoamines and acetylcholine containing neurons in the regulation of the sleep-waking cycle, p. 166-307. In R. M. Adrian, Neurophysiology and Neurochemistry of Sleep and Wakefulness, Spring Verlag, Berlin.

JOUVET, M., 1973. Role of catecholamines in the control of the sleep-waking cycle, p. 751.757. In E. Usdin \& S. H. Snyder (eds), Frontiers in Catecholamine Research, Pergamon Press, Great Britain.

KOBINGER, W., 1978. Central alpha-adrenergic systems as targets for hypotensive drugs. Rev. Physiol. Biochem. Pharmacol, 81: 39-100.

KOENIG-BERARD, E.; TIERNEY, C.; BEAU, C.; DELBARRE, G.; LHOSTE, F. \& LABRID, C., 1988. Cardiovascular and central nervous system effects of rilmenidine in rats. Am. J. Cardiol., 61: 22D23D.

LAMBAS-SENAS, L.; GILLON, I.; BOUILLOUX, J. P.; SECCIA, M.; BUDA, M. \& RENAUD, B., 1990. In vivo monitoring of catecholaminergic metabolism in the $\mathrm{Cl}$ region of rat medulla oblongata: $A$ comparative study by voltammetry and intracerebral microdialysis. J. Neurochem., 54: 2042-2049.

LANGIN, D. \& LAFONTAN, M., 1989. [3lI]idazoxan binding at non alpha2-adrenoceptors in rabbit adipocyte membranes. Eur. J. Pharmacol, 159: 199203.

LAUBIE, M.; POIGNANT, J, C.: SCUVEE-MOREAU, J.; DRESSE, A. \& SCHMITT, H., 1985. Pharmacological properties of ( $\mathrm{N}$-dicyclopropyl-methylamino2-oxazoline ( $\$ 3341$ ), an alpha2-adrenoceptor agonist. J. Pharmacol. (Paris), I6: 259.

LIMON, I.; COUPRY, I.; LANIER, S. M. \& PARINI, A., 1992. Characterization of motochondrial imidazoline-guanidinium receptive site from rabbit kidney. Fundam. Clin. Pharmacol. 2 (suppl 1): 46s.

McAULEY, M. A.; MACRAE, l. M. \& REID, J. L., 1989. The cardiovascular actions of clonidine and neuropeptide $Y$ in the ventrolateral medulla of the rat. Br. J. Pharmacol, 97: 1067-1074.

MEELEY, M. P.; ERNSBERGER, P. R.; GRANATA, A. R. \& REIS, D. J., 1986. An endogenous clonidinedisplacing substance from bovine brain: receptor binding and hypotensive actions in the ventrolateral medulla. Life $S_{c i .}$, 38: 1119-1126.

MICHEL, M. C.; BRODDE, O-E; SCHNEPEL, B.; BEHRENDT, J.; TSCHADA, R.; MOTULSKY, $H$. J. \& INSEL, P. A., 1989. [ $\left.{ }^{3} \mathrm{H}\right]$ idazoxan and some 
other alpha2-adrenergic drugs also bind with high affinity to a nonadrenergic site. Mol. Pharmacol. 35: 324-330.

MICHEL, M. C.; REGAN, J. W.; GERJIARDT. M. A.; NEUBIG, R. R.; INSEL, P. A. \& MOTULSKY, H. J., 1990. Nonadrenergic $\left[{ }^{3} \mathrm{H}\right]$ idazoxan binding sites are physically distinct from alpha2-adrenoceptors. Mol. Pharmacol., 37: 65-68.

PARINI, A.; COUPRY, I.; GRAHAM, R. M.; UZIELLI, I.; ATLAS, D. \& LAMER, S. M., 1989. Characterization of an imidazoline/guanidinium receptive site distinct from the alpha2-adrenoceptor. J. Biol. Chem. 264: 11874-11878.

PORTILLO, M.; REVERTE, M.; LANGIN, D.; SENARD, J. M.; TRAN, M. A.; BERLAN, M. \& MONTASTRUC, J. L., 1991. Effect of a 7-day treatment with idazoxan and its 2 -methoxy derivative RX 821002 on alpha2-adrenoceptors and on nonadrenoceptor binding sites in rabbits. Br. J. Pharmacol., 104: 190-194.

REDMOND Jr., D. E., 1981. Clonidine and the primate locus coeruleus: Evidence suggesting anxyolitic and antiwithdrawal effects, p. 147-163. In H. Lal \& S. Fielding (eds), Psycopharmacology of Clonidine. Alan Liss Inc., New York.

REIS, D. J.; MORRISON, S. \& RUGGIERO, 1988. The $C I$ area of the brainstem in tonic and reflex control of blood pressure. Hypertension, 11 (suppl. 1): I7113.

REIS, D. J.; REGUNATIIAN, S.; WANG, H.; FEINSTEIN, D. L. \& MEELEY, M. P., 1992. Imidazoline receptors in the nervous system. Fundam. C/in. Pharmacol. 6 (suppl 1): 23s-29s.

ROCKSON, S. G.; HOMCY, C. J. \& HABER, E., 1980. Anti-alprenolol antibodies in the rabbit: A new probe for the study of beta-adrenergic receptor interaction. Circ. Res., 46: 808-813.

RUFFOLO, R. R., 1991. Structure-activity relationship of alpha-adrenoceptor agonists and antagonists, p. 5-14. In E. Szabadi \& C. M. Bradshaw (eds), Adrenoceptors: Structure, mechanisms and functions, Birkhäuser Verlag, Berlin.

SUAUD-CHAGNY, M. F.; STEINBERG, R.; MERMET, C.; BIZIERE, R. \& GONON, F., 1986. In vivo monitoring of catecholamine metabolism in the Al and A2 regions of the rat medulla oblongata. $J$. Ncurochem. 47: 1141-1147.

TIBIRICA, E.; FELDMAN, J. \& BOUSQUET, 1988. Differences in the ability of yohimbine to antago- nize the hypotensive effect of clonidine in the normotensive and spontaneously hypertensive anesthetized rats. J. Pharmacol. Exp. Ther., 244: 10621066.

TIBIRICA, E.; FELDMAN, J.; MERMET, C.; GONON, F. \& BOUSQUET, P., 1991 a. An imidazoline specific mechanism for the hypotensive effect of clonidine: A study with yohimbine and idazoxan. $J$. Pharmacol. Exp. Ther, 256: 606-613.

TIBIRICA, E.; FELDMAN, J,; MERMET, C.; MONASSIER, L.; GONON, F. \& BOUSQUET, P., 1991b. Selectivity of rilmenidine for the nucleus reticularis lateralis, a ventrolateral medullary structure containing imidazoline-preferring receptors. Eur. J. Pharmacol, 209: 213-221.

TIBIRICA, E.; MERMET, C.; FELDMAN, J.; GONON, F. \& BOUSQUET, P., 1989. Correlation between the inhibitory effect on catecholaminergic ventrolateral medullary neurons and the hypotension evoked by clonidine: a voltammetric approach. $J$. Pharmacol. Exp. Ther., 250: 642-647.

TIMMERMANS, P. B. M. W. \& VAN ZWIETEN, P. A., 1982. Alpha2-adrenoceptors: classification, localization, mechanisms and target for drugs. $J$. Med. Chem., 25: 1389-1401.

VAN ZWIETEN, P. A.; THOOLEN, M. J. M. C.; JONKMAN, F. A. M.; WILLFERT, B.; De JONG, A. \& TIMMERMANS, P. B. M. W. M., 1986. Central and peripheral effects of S3341 [(N-dicyclopropyl-methylamino-2-oxazoline)] in animal models. Arch. Int. Pharmacodyn., 279: 130.

WIKBERG, J. E. S., 1989. High affinity binding of idazoxan to a non-catecholaminergic binding site in the central nervous system: Description of a putative idazoxan receptor. Pharm. Toxicol., 64: 152-155.

WIKBERG, J. E. S. \& UHLEN, S., 1990. Further characterization of the guinea pig cercbral cortex idazoxan receptor. Solubilization, distinction from the imidazoline site and demonstration of cirazoline as an idazoxan receptor-selective drug. $J$. Neurochem., 55: 192-203.

WOLF, D. L. \& MOHRLAND, J. S., 1984. Lateral reticular formation as a site for morphine and clonidine induced hypotension. Eur. J. Pharmacol., 98: 93 98.

YABLONSKY, F.; RIFFAUD, J. P. \& DAUESE, J. P., 1988. Evidence for nonadrenergic binding sites for $\left[{ }^{3} \mathrm{H}\right]$ idazoxan in the smooth muscle of rabbit urethra. Eur. J. Pharmacol., /54: 209-212. 